\title{
Damage to the Right Rectus Abdominus Muscle and Hematoma of the Right Uterine Broad Ligament: Rare Complications of a Road Accident during Pregnancy
}

Koffi A, Effoh D, Gondo D, Alla C, Gbary E, Kouassi A and Loue V*

Houphouet Boigny's University of Cocody-Abidjan, Faculty of Medical Sciences, Mother-Child Department, University Hospital of Cocody, France

\begin{abstract}
Summary
Severe damage to the right rectus abdominus muscle associated with a uterine broad right ligament hematoma is rare complications of an accident during pregnancy. We report the case of a 31 years old primiparous pregnant woman, who had been victim of a road accident at 28 weeks of pregnancy, when as a pediatrian she was hit by a car. The site of impact was in the right anterolateral area on the abdomen. The pregnancy continued normally and she was ultimately delivered vaginally at 41 weeks of gestation. The baby was normally grown and had Apgar scores of 9 and 10 at 1 and 5 minutes of life. She underwent a laparotomy in the immediate postpartum period for a significant hemoperitoneum; this revealed the lesions and allowed treatment. The postoperative course was uneventful and the patient was discharged on the 6th post-partum day.
\end{abstract}

Keywords: Abdominal trauma; Fetal outcome; Pregnancy

\section{Introduction}

Trauma during pregnancy has become relatively common. In developed countries where statistics are well defined, 6 to $7 \%$ of road accidents involve pregnant women [1-3] and are the commonest nonobstetric cause of fetal death. In severe injuries the fetal death rate is near $60 \%$ and the maternal death rate close to $10 \%$ [4]. We report a case of a road accident in a pregnant woman without consequences for the mother and child until after delivery.

\section{Case Presentation}

Mrs. EB, a 31 year-old primiparous pregnant woman, who had a four year old child born vaginally, was 28 weeks pregnant when she was hit by a taxi. The impact site was at the right anterolateral area of the abdomen and projected her for about 2 meters from the site of impact. There was no initial loss of consciousness. Without waiting for the arrival of emergency medical assistance, she was transported to a medical center. The general practitioner here diagnosed that there would be no problem, because her hemodynamic status was stable and the fetal heart rate was normal. The patient was not observed further and no further investigations were performed. She received only analgesics and dressing of a contused wound of the right knee. The rest of antenatal consultations with midwives and an outside referral service were apparently normal although she did indicate she had some abdominal pain requiring analgesic and antispasmodic therapy.

Three months after the accident, she was admitted to our service in labor at 41 weeks gestation. On admission, the general condition was good and the blood pressure was $130 / 80 \mathrm{mmHg}$. The abdomen was soft between contractions but slightly sensitive at the hypogastric level. The uterine height was $34 \mathrm{~cm}$. At the time of admission the cervix was $4 \mathrm{~cm}$ dilated, the membranes were still intact and the cephalic presentation was fixed in the pelvic cavity but not engaged. Fetal heart rate monitoring was normal and reactive with a baseline rate of $148 \mathrm{bpm}$.

Two hours after admission, she was delivered vaginally of a newborn male baby weighing $3100 \mathrm{gm}, 49 \mathrm{~cm}$ in length and with a head circumference of $34 \mathrm{~cm}$. The Apgar scores were 9 and 10 at 1 and 5 minutes of life. The placenta was delivered by controlled cord traction as is practiced in our service followed by the continuous infusion of oxytocin. Three hours after delivery, the patient complained of sharp pelvic pain. Clinical examination noted a fall in blood pressure $(\mathrm{BP}=90 / 05 \mathrm{mmHg})$, conjunctival pallor and pelvic tenderness with slight release tenderness. The uterus was well contracted, and vaginal blood loss was not increased. Because we do not have ultrasound in the delivery room, a culdocentesis was performed and revealed a hemoperitoneum. This finding resulted in an emergency laparotomy being performed, preceded by a fluid and electrolyte resuscitation including a blood transfusion. The hemoglobin level before surgery was $61 \mathrm{~g} / \mathrm{L}$.

Intraoperatively, we found significant damage to the lower third of the right rectus abdominus muscle, associated with a right broad ligament hematoma extending from the right edge of the uterus to the base of the ligament. There was also an abundant hemoperitoneum. The uterus was well contracted and was intact.

The surgical procedure then involved a flattening of blood clots within the muscle with hemostasis and clot removal (about 200g of old clots) after dissection of the broad ligament followed by abdominal toilet. Blood pressure at the end of surgery was $80 / 60 \mathrm{mmHg}$. The blood loss was estimated at 1.8 liters, with the patient receiving a blood transfusion of a liter of red cells intra and post-operatively. The postoperative course was uneventful and discharge from hospital occurred on the 6 th post-delivery day.

${ }^{*}$ Corresponding author: Dr. Loue Védi Andre Serges, CHU de Cocody, $01 \mathrm{BP}$ V13 Abidjan -Cote, France, Tel : 00225490000 40; Fax: 00225053151 02; E-mail: drlouevedi@yahoo.fr

Received October 01, 2013; Accepted October 10, 2013; Published October 15, 2013

Citation: Koffi A, Effoh D, Gondo D, Alla C, Gbary E, et al. (2013) Damage to the Right Rectus Abdominus Muscle and Hematoma of the Right Uterine Broad Ligament: Rare Complications of a Road Accident during Pregnancy. Clinics Mother Child Health 11: 155. doi: 10.4172/2090-7214.1000155

Copyright: (C) 2013 Koffi A, et al. This is an open-access article distributed under the terms of the Creative Commons Attribution License, which permits unrestricted use, distribution, and reproduction in any medium, provided the original author and source are credited. 
Citation: Koffi A, Effoh D, Gondo D, Alla C, Gbary E, et al. (2013) Damage to the Right Rectus Abdominus Muscle and Hematoma of the Right Uterine Broad Ligament: Rare Complications of a Road Accident during Pregnancy. Clinics Mother Child Health 11: 155. doi: 10.4172/20907214.1000155

Page 2 of 2

\section{Discussion}

Trauma during pregnancy is common, however in Cote d'Ivoirethere are no reliable records of accidents and studies on large populations in our country. Only a short series of seven cases resulting in fractures in pregnant patients has been reported [5]. In developed countries road accidents affect 5 to $7 \%$ of pregnancies [1-3] and are the leading cause of maternal deaths of non-obstetric origin between the age of 14 and 44 years [1]. These injuries are underestimated and represent $55 \%$ of non-penetrating abdominal trauma in pregnant women $[1,6,7]$. Whether minor or serious, traffic accidents are prone to complications in both the mother and the fetus. The risk of perinatal complications is directly proportional to their intensity and especially the mechanism of abdominal trauma [8]. The most common obstetric complications are premature rupture of membranes and preterm delivery, placental abruption, fetal injury (fracture, acute fetal distress, and fetal death), uterine rupture and feto-maternal hemorrhage [8-10].

The detachment and the damage of the rectus abdominus muscle associated with a hematoma of the right broad ligament, as observed in our patient, appear exceptional as does the fact they were of no real significance to the mother or her fetus until after delivery. The absence of placental abruption, fetal injury or uterine rupture in our case seems difficult to explain given the state of the right rectus muscle and the broad ligament hematoma which presumably resulted from the trauma in that region. If a placental abruption had occurred, signs related to it would probably would have attracted the attention of the general practitioner who examined the patient soon after the accident.

In general, the management and monitoring of a pregnant victim of a road accident (regardless of gestational age, the seat of the traumatic impact point and the importance of shock) must be performed in a specialized service. The initial physical examination, given its fundamental forensic significance [9] must be complete and thorough as clinical symptoms in pregnant women traumatized may wander due to physiological changes associated with pregnancy. In our department, Ultrasonography is routine at the time of admission to assess fetal wellbeing and look for fetal harm, renewed after 48 to 72 hours because of the risk of a previously undetected placenta abruption. International studies indicate that cardiotocographic assessments of the fetal heart rate should be performed repeatedly for at least 24 hours and that a full blood examination and Kleihauer test should also be performed.

When all these tests are normal, an injured pregnant woman should be hospitalized for 72 hours and consideration given to the use of preventive or curative tocolysis. She can then be discharged in the absence of non-obstetric injuries requiring care in other specialties. Antenatal clinic attendances are then necessary until the end of the pregnancy, with the possibility of reduced fetal growth resulting from an undetected placental abruption being assessed. Our patient was seen by a general practitioner and thus could not have benefitted from such compliance measures.

The maternal and fetal hemodynamic stability observed until delivery was probably due to a spontaneous hemostasis of lesions [8] and the physiological changes associated with pregnancy. Indeed, an early increase in cardiac output and blood volume can compensate for significant loss blood [5]. The resumption of bleeding which led the hemoperitoneum in the postpartum period was probably due to the labor itself.

\section{Conclusion}

Trauma to a pregnant woman, irrespective of its intensity and the lack of any resulting shock, is a potential danger to both the mother and fetus. The complete and thorough initial examination and a methodical and rigorous para-clinical supervision in a specialized service is necessary to allow the early detection of any complications and to provide better overall care.

\section{References}

1. El-Kady D, Gilbert WM, Anderson J, Danielsen B, Towner D, et al. (2004) Trauma during pregnancy: an analysis of maternal and fetal outcomes in a large population. Am J ObstetGynecol 190: 1661-1668.

2. Moorcroft DM, Stitzel JD, Duma GG, Duma SM (2003) Computational model of the pregnant occupant: predicting the risk of injury in automobile crashes. Am J ObstetGynecol 189: 1540-1544.

3. Werawatakul Y, Chaivoramukkul C (2004) Maternal knownledge, attitude and practice of the safety belt use during pregnancy at Srinagaring hospital. J Med Assoc Thai 87: 59-65.

4. Mirza FG, Devine PC, Gaddipati S (2010) trauma in pregnancy: a systematic approach. Am J perinatol 27: 579-86.

5. Kouame KM, Anoumou NM, Traore M, Kirioua BJ, Varango GG (2009) Traumatismes et grossesse. Analyse rétrospective d'une courte série de 7 cas au Centre Hospitalier de Treichville Abidjan (Cote d'Ivoire). Med Afr Noire 56: 301-304.

6. Vaysse C, Mignot F, Benezech J-P, Parant O (2007) Rupture uterine traumatique: une complication rare des accidents de la voie publique au cours de la grossesse. A propos d'un cas. J GynecolObstétBiolReprod 36: 611-614.

7. Mattox KL, GoetzI L (2005) Trauma in pregnancy. Crit Care Med 33: S385-9.

8. Barré M, Winer N, Caroit Y, Boog G, Philippe H-J (2006) Traumatisme au cours de la grossesse: pertinence des éléments de surveillance dans l'évaluation des suites obstétricales. A propos d'une série de 98 patientes. J GynecolObstétBiolReprod 35 : 673-7.

9. Occeli B, Depret-Mosser S, Renault B, Therby D, Codaccioni X (1998) Traumatisme du bassin et grossesse. Revue de la littérature à propos d'un cas. ContraceptFertilSex $1998 ; 26,12:$ 869-75.

10. Vendittelli F, Manciet-Labarchede C, Fabaste JL, Malinas Y (1994) Lésions traumatiques de l'utérus gravide et de son contenu : aspect médico-légaux. Rev frGynécolObstét 89: 393-400. 